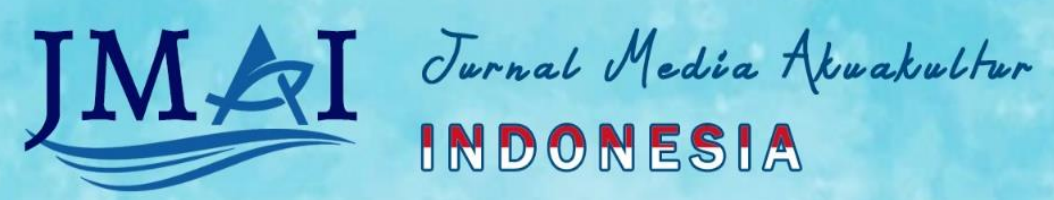

https://journal.unram.ac.id/index.php/jmai/index. E-ISSN : 2798-0553

VOLUME 1, NOMOR 2, DESEMBER 2021

\title{
ANALISIS KUALITAS AIR BUDIDAYA SEGI FISIKA PERAIRAN KECAMATAN SANGIA WAMBULU KABUPATEN BUTON TENGAH
}

\author{
Ismail Failu, Bahtiar Hamar, Abdul Hadi Bone, Yusti Sitania
}

\section{Jurusan Pengelolaan Sumberdaya Perairan Universitas Muhammadiyah Buton}

Jalan Betoambari No. 36 Telp. (0402) 2822913 Fax. (0402) 2822913 Kota Baubau Sulawesi

Tenggara

\section{Alamat Korespondensi : ismailfailu86@gmail.com}

\begin{abstract}
ABSTRAK
Tujuan dari penelitian ini adalah untuk mendemonstrasikan kelayakan budidaya ikan dan rumput laut di perairan sekitar Kecamatan Sangia Wambulu, ditinjau dari aspek fisika perairan. Penelitian dilaksanakan mulai bulan April sampai dengan Mei 2021 bertempat di Perairan Kecamatan Sangia Wambulu Kabupaten Buton Tengah. Alat yang digunakan pada penelitian adalah : Seichidisk, Termometer, Refraktometer, Perahu, Senter, Layangan arus, Tali raffia, Stopwatch dan Waterpass. Bahan yang digunakan dalam penelitian adalah air sampel yang diambil dari Spot yang sudah ditentukan lokasinya. Metode yang digunakan dalam penelitian ini adalah metode deskriptif analitis. Metode deskriptif analitis dapat diartikan sebagai prosedur penelitian yang berusaha mendeskripsikan suatu gejala, peristiwa ataupun kejadian, menggambarkan variabel demi variabel serta mengumpulkan informasi berdasarkan fakta-fakta yang tampak atau sebagaimana adanya, kemudian di analisis (Hasan, 2002). Teknik pengambilan sampel yang digunakan yaitu Purposive Sampling. Purposive Sampling adalah pengambilan sampel berdasarkan keperluan penelitian, artinya setiap unit atau individu yang diambil dari populasi dipilih dengan sengaja berdasar pertimbangan tertentu (Purwanto dan Dyah, 2007). Berdasarkan hasil pengamatan dan pembahasan yang telah dilakukan maka pentingnya menarik beberapa kesimpulan yaitu : Parameter fisik yaitu suhu perairan berkisar 26 hingga 28ㅇ C, salinitas 29 - 31 ppt, kecerahan 5 hingga 7,3 m, dan kecepatan arus 7,01 - 11,38 cm/detik. Secara umum keberadaan kualitas air fisik; suhu dan kecerahan masih berada pada kondisi yang relatif baik. Pada dasarnya perairan Kecamatan Sangia Wambulu yakni sekitar Desa Baruta Analalaki, Baruta Doda dan Tolandona masih dapat di gunakan usaha budidaya.
\end{abstract}

Kata Kunci Kualitas air, Suhu, Salinitas, Kecerahan dan Kecepatan Arus

Tracebility Tanggal diterima : 24/06/2021. Tanggal dipublikasi : 12/12/2021

Panduan

Kutipan

(APPA $7^{\text {th }}$ )

Failu, I., Hamar, B., Bone, A. H, \& Sitania, Y. (2021). Analisis Kualitas Air Budidaya Segi

Fisika Perairan Kecamatan Sangia Wambulu Kabupaten Buton Tengah. Jurnal Media $\begin{array}{llll}\text { Akuakultur } & \text { Indonesia, } & 1 & \text { (2), }\end{array}$ http://doi.org/10.29303/mediaakuakultur.v1i2.226 


\section{PENDAHULUAN}

Indonesia adalah salah satu negara kepulauan terbesar di dunia, dengan lebih dari 17.000 pulau. Indonesia adalah negara dekat khatulistiwa dengan 17.508 pulau dan garis pantai sekitar 81.407 kilometer (Prasetya, 2013). Meskipun lautan menutupi dua pertiga dari luas daratan, negara ini memiliki persediaan air yang sangat besar. Di perairan Indonesia, seperti yang ada di dekat Desa Baruta Lalaki di Kabupaten Sangia Wambulu, pengembangan sumber daya laut sangat memungkinkan. Ada dua desa di perairan sekitar Desa Baruta Lalaki di Kecamatan Sangia Wambulu, yaitu Desa Baruta Doda dan Desa Tolandona. Mayoritas kegiatan masyarakat di kedua desa tersebut adalah petani, nelayan, dan pembudidaya rumput laut.

Akibat praktik tata guna lahan untuk pertanian dan permukiman di kedua desa tersebut, kualitas air di perairan Desa Baruta Lalaki, Kecamatan Sangia Wambulu, mengalami penurunan kualitas. Sedimentasi dari air limbah dan pembuangan limbah dari permukiman akan meningkatkan pencemaran laut pada ekosistem di sekitar wilayah studi, yang menyebabkan peningkatan kekeruhan laut dan penurunan kualitas air yang kesemuanya akan berdampak pada habitat organisme akuatik (Rangga et al, 2018). Kualitas air yang baik menurut Effendi (2003) merupakan syarat mutlak untuk produksi ikan.

Sebagai konsekuensinya, penting untuk memastikan standar kualitas air yang membatasi bentuk biota air yang dapat dibudidayakan di berbagai badan air. Mengingat pentingnya kualitas air maka diperlukan penelitian tentang parameter fisik kualitas air di perairan Kecamatan Sangia Wambulu, yang selanjutnya dapat digunakan sebagai indikator keberlanjutan budidaya ikan dan rumput laut.

\section{METODE PENELITIAN}

Penelitian ini dilaksanakan mulai bulan April sampai dengan Mei 2021 bertempat di Perairan Kecamatan Sangia Wambulu Kabupaten Buton Tengah. Alat yang digunakan pada penelitian adalah : Seichidisk, Termometer, Refraktometer, Perahu, Senter, Layangan arus, Tali raffia, Stopwatch dan Waterpass. Bahan yang digunakan dalam penelitian adalah air sampel yang diambil dari Spot yang sudah ditentukan lokasinya.

Metode pengambilan sampel yang digunakan yaitu Purposive Sampling. Purposive Sampling adalah pengambilan sampel berdasarkan keperluan penelitian, artinya setiap unit atau individu yang diambil dari populasi dipilih dengan sengaja berdasar pertimbangan tertentu (Purwanto dan Dyah, 2007).

Penentuan titik pengambilan sampel terbagi atas 3 Spot yang sebelumnya dilakukan observasi lokasi untuk mendapatkan gambaran umum mengenai lokasi-lokasi yang nantinya akan dijadikan sebagai titik pengambilan sampel di perairan Kecamatan Sangia Wambulu kecamatan Kapuntori. Posisi pengambilan dicatat dengan bantuan Global Positioning System (GPS).

Pengambilan sampel di tiap Spot dilakukan sebanyak 3 kali. Adapun Spot pengambilan sampel tersebut yaitu:

- Lokasi 1 terletak di perairan Desa Baruta Analalaki, terdapat 3 titik pengambilan sampel yaitu Spot 1, 2 dan 3. Jarak setiap Spot \pm 100 meter. 
- Lokasi 2 terletak di perairan Desa Baruta Doda (diantara lokasi 1 dan 3), terdapat 3 titik pengambilan sampel yaitu Spot 4,5 dan 6. Jarak setiap Spot \pm 100 meter.

- Lokasi 3 terletak di perairan Desa Tolandona, terdapat titik pengambilan sampel yaitu Spot 7, 8 dan 9. Jarak setiap Spot \pm 100 meter.

\section{Prosedur Kerja}

- Suhu. Pengambilan suhu air sampel penelitian dengan menggunakan alat thermometer, kemudian dimasukkan ke dalam air laut secara pelan-pelan, kemudian thermometer yang menunjukan suhu lalu dicatat nilainya. Pengambilan air sampel dilakukan setiap 3 kali dalam seminggu yakni pada hari minggu, selasa, dan kamis dengan selang waktu 4 jam.

- Salinitas. Air sampel yang terdapat pada botol aqua diteteskan pada kaca obyektif Hand Refraktometer, lalu hadapkan Hand Refraktometer pada daerah yang terang kemudian dilihat skala yang menunjukan nilai salinitas kemudian dicatat.

- Layangan angin atau arus. Layangan angin yang diikat dengan tali beberapa meter (sesuai kebutuhan) kemudian diletakkan diatas permukaan air lalu dibiarkan berjalan samapi panjang tali yang diikatkan terentang yang diikutkan dengan waktu kemudian dicatat beberapa meter per satuan waktu.

- Kecerahan. Piring Seichidisk dimasukkan ke dalam perairan sampai tidak kelihatan dasar putihnya kemudian ditarik secara perlahan-lahan sampai warna dasar putih kelihatan lalu ditandai untuk diukur beberapa meter kecerahan.

- Pasang Surut. Disiapkan alat yang akan digunakan yaitu tide staff, kemudian dibawa keperairan pantai lalu ditancapkan didasar perairan. Diukur ketinggian awal permukaan laut dan dicatat, setelah itu didiamkan selama kurang lebih 4 jam lalu dicatat ketinggian permukaan laut kemudian dihitung nilai pasang surutnya dengan rumus: Pasang Surut $=\frac{t 1-t o}{T}$, dimana $\mathrm{t}_{1}$ adalah skala akhir pada tide staff, $\mathrm{t}_{0}$ adalah skala awal pada tide staff dan T adalah selang waktu pengukuran.

\section{Analisis Data}

Dari hasil pengamatan parameter fisika air seperti suhu, salinitas, kecerahan, kecepatan arus, di analisis secara deskriptif yang disajikan dalam bentuk tabel dan gambar untuk menjelaskan kelayakan kualitas air Spot pengamatan untuk pengembangan kegiatan budidaya rumput laut dan ikan.

\section{HASIL DAN PEMBAHASAN}

\section{Suhu}

Hasil pengukuran suhu pada lokasi penelitian tersaji pada tabel 2 dan gambar 2 dibawah ini.

Tabel 2. Rata-rata suhu perairan selama bulan April sampai dengan bulan Mei 2021.

\begin{tabular}{ccccccccc}
\hline \multirow{2}{*}{ Lokasi } & \multirow{2}{*}{ Spot } & Parameter & \multicolumn{3}{c}{ April 2021 } & \multicolumn{3}{c}{ Mei 2021 } \\
\cline { 4 - 9 } & & Suhu $\left({ }^{\circ} \mathbf{C}\right)$ & Pagi & Siang & Sore & Pagi & Siang & Sore \\
\hline \multirow{2}{*}{ I } & $\mathbf{1}$ & Kisaran & 27 & 28 & 27 & $26-28$ & $28-29$ & $27-28$ \\
& $\mathbf{2}$ & Kisaran & 27 & 28 & 27 & $26-28$ & $28-29$ & $27-28$
\end{tabular}




\begin{tabular}{|c|c|c|c|c|c|c|c|c|}
\hline $\begin{array}{c}\text { Baruta } \\
\text { Analalaki }\end{array}$ & 3 & Kisaran & 27 & 28 & 27 & $26-28$ & $28-29$ & $27-28$ \\
\hline \multicolumn{3}{|c|}{ Rata-rata } & 27 & 28 & 27 & 26.75 & 28.25 & 27.25 \\
\hline II & 4 & Kisaran & 27 & 28 & 27 & $26-28$ & $28-29$ & $27-28$ \\
\hline Baruta & 5 & Kisaran & 27 & 28 & 27 & $26-28$ & $28-29$ & $27-28$ \\
\hline Doda & 6 & Kisaran & 27 & 28 & 27 & $26-28$ & $28-29$ & $27-28$ \\
\hline \multicolumn{3}{|c|}{ Rata-rata } & 27 & 28 & 27 & 26.75 & 28.25 & 27.25 \\
\hline \multirow{3}{*}{$\begin{array}{c}\text { III } \\
\text { Tolandona }\end{array}$} & 7 & Kisaran & 27 & 28 & 27 & $26-28$ & $28-29$ & $27-28$ \\
\hline & 8 & Kisaran & 27 & 28 & 27 & $26-28$ & $28-29$ & $27-28$ \\
\hline & 9 & Kisaran & 27 & $27-28$ & 27 & $26-28$ & $28-29$ & $27-28$ \\
\hline \multicolumn{3}{|c|}{ Rata-rata } & 27 & 27.5 & 27 & 26.75 & 28.25 & 27.25 \\
\hline
\end{tabular}

Hasil pengamatan suhu perairan lokasi penelitian menunjukkan bahwa kisaran suhu pada bulan April 2021, saat pagi dan sorei hari berkisar 27으, sedang pada siang hari suhu perairan berkisar 28으. Pada bulan Mei 2021, saat pagi dan sore hari berkisar 26-28을 sedang pada siang hari suhu perairan berkisar $28-29^{\circ} \mathrm{C}$.

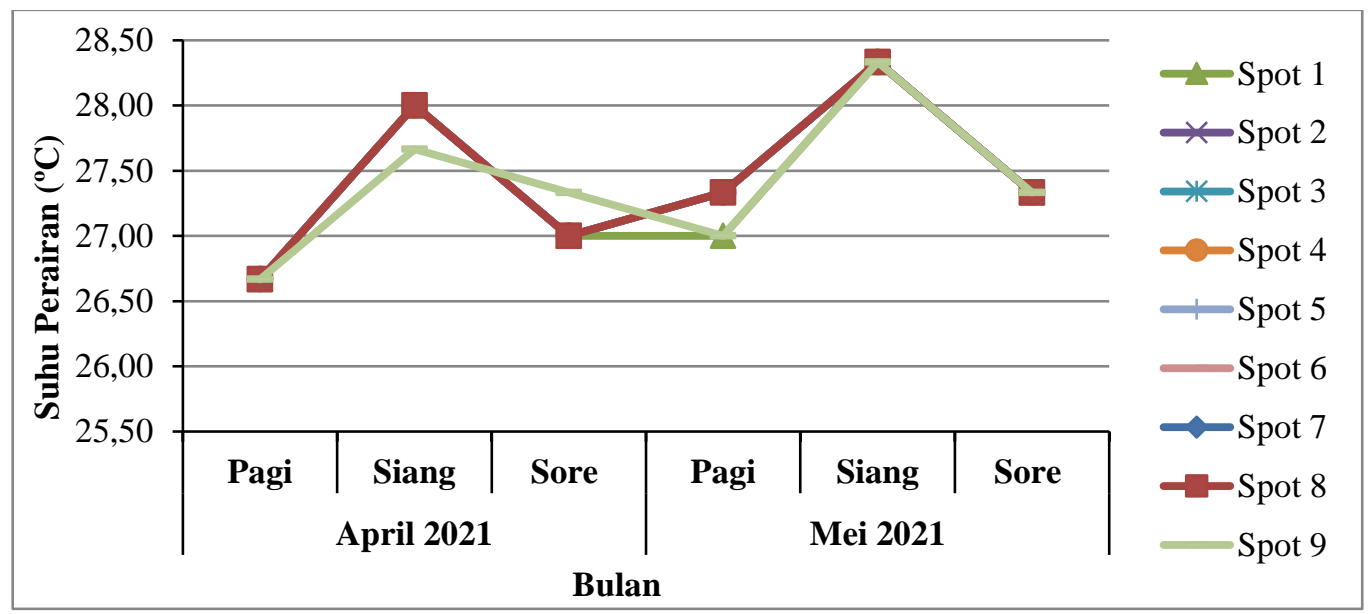

Gambar 2. Grafik Suhu Perairan Pada 9 Spot Pengamatan Berbeda Spot.

Hasil pengamatan menunjukkan suhu air laut terandah pada tanggal 17 Mei pada setiap Spot yakni kisaran antara $26^{\circ} \mathrm{o}$. Hal ini disebabkan pada saat penelitian cuaca bulan Mei mengalami perubahan iklim yakni mendung sehingga matahari tertutupi oleh awan. Sedang suhu air laut tertinggi terjadi pada siang hari yang berkisar antara 29 o $\mathrm{C}$ dengan rata-rata 28,50 terjadi pada tanggal 31 Mei pada setipa Spot. Hal ini disebabkan karena pada siang hari posisi matahari berada tepat vertikal dengan bumi sehingga intensitas cahaya meningkat yang akhirnya meningkatkan suhu perairan. Suhu suatu perairan dipengaruhi oleh radiasi matahari, posisi matahari, letak geografis, musim, kondisi awan, serta proses interaksi antara air dan udara, penguapan, dan hembusan angin (Nirmala 2014; Boyd 1982). Menurut Effendi (2003), perubahan suhu berpengaruh terhadap proses fisika, kimia, dan biologi badan air. Secara umum, suhu rata-rata di Perairan Spot Fakultas Perikanan dan Ilmu Kelautan pada Kecamatan Sangia Wambulu Kecamatan Kapuntori Kabupaten Buton menunjukkan nilai yang masih mendukung untuk kegiatan budidaya ikan dan rumput laut. 
Suhu memiliki peranan penting dalam proses tumbuh rumput laut. Menurut Neish (2003) suhu air yang sesuai dengan kebutuhan hidup rumput laut Kappaphycus alvarezii adalah berkisar pada $28-32^{\circ}$ C. Kenaikan temperatur yang tinggi akan mengakibatkan thallus rumput laut menjadi pucat kekuningan dan tidak sehat, rumput laut dapat tumbuh dengan baik pada kisaran suhu $26-32^{\circ} \mathrm{C}$ (DKP, 2006).

Menurut Kordi (2010) suhu yang ideal bagi kehidupan ikan kerapu tikus adalah 27$32^{\circ} \mathrm{C}$. Dengan demikian suhu dengan kisaran antara $28 \stackrel{\circ}{\circ} \mathrm{C}-29 \stackrel{\circ}{\circ} \mathrm{C}$ sudah memenuhi syarat untuk pemeliharaan ikan kerapu tikus. Suhu perairan mempunyai peranan sangat penting dalam pengaturan aktivitas, pertumbuhan, nafsu makan, dan mempengaruhi proses pencernaan makanan.

\section{Salinitas}

Hasil pengukuran salinitas pada lokasi penelitian tersaji pada tabel 3 dan gambar 3 dibawah ini.

Tabel 3. Rata-rata salinitas perairan selama bulan April sampai dengan bulan Mei 2021.

\begin{tabular}{|c|c|c|c|c|c|c|c|c|}
\hline \multirow{2}{*}{ Lokasi } & \multirow{2}{*}{ Spot } & \multirow{2}{*}{$\begin{array}{c}\text { Parameter } \\
\text { Salinitas }\end{array}$} & \multicolumn{3}{|c|}{ April 2021} & \multicolumn{3}{|c|}{ Mei 2021} \\
\hline & & & Pagi & Siang & Sore & Pagi & Siang & Sore \\
\hline \multirow{6}{*}{$\begin{array}{c}\text { I } \\
\text { Baruta } \\
\text { Analalaki }\end{array}$} & \multirow[t]{2}{*}{1} & Kisaran & $28-30$ & $31-34$ & $28-30$ & $29-30$ & $30-33$ & $30-34$ \\
\hline & & Rata-rata & 29 & 32.5 & 29 & 29.75 & 31.75 & 33 \\
\hline & \multirow[t]{2}{*}{2} & Kisaran & $29-30$ & $33-34$ & 30 & $29-30$ & $30-33$ & $30-34$ \\
\hline & & Rata-rata & 29.5 & 33.5 & 30 & 29.75 & 31.75 & 33 \\
\hline & \multirow[t]{2}{*}{3} & Kisaran & $29-30$ & $33-34$ & 30 & 30 & $32-34$ & $30-34$ \\
\hline & & Rata-rata & 29.5 & 33.5 & 30 & 30 & 33 & 32 \\
\hline \multirow{6}{*}{$\begin{array}{c}\text { II } \\
\text { Baruta } \\
\text { Doda }\end{array}$} & \multirow[t]{2}{*}{4} & Kisaran & $29-30$ & $33-34$ & 30 & 30 & $32-34$ & $30-34$ \\
\hline & & Rata-rata & 29.5 & 33.5 & 30 & 30 & 33.5 & 31 \\
\hline & \multirow[t]{2}{*}{5} & Kisaran & 30 & $32-34$ & $30-33$ & 30 & $32-34$ & $30-34$ \\
\hline & & Rata-rata & 30 & 33 & 31.5 & 30 & 32.5 & 33 \\
\hline & \multirow{2}{*}{6} & Kisaran & 30 & $32-34$ & $30-33$ & 30 & $32-34$ & $30-34$ \\
\hline & & Rata-rata & 30 & 33 & 31.5 & 30 & 33.5 & 31 \\
\hline \multirow{6}{*}{$\begin{array}{c}\text { III } \\
\text { Tolandona }\end{array}$} & \multirow[t]{2}{*}{7} & Kisaran & 30 & $32-34$ & $30-33$ & 30 & $32-34$ & $30-33$ \\
\hline & & Rata-rata & 30 & 33 & 31.5 & 30 & 33.5 & 30.75 \\
\hline & \multirow[t]{2}{*}{8} & Kisaran & 30 & 34 & 30 & 30 & $32-34$ & $30-33$ \\
\hline & & Rata-rata & 30 & 34 & 30 & 30 & 33.5 & 30.75 \\
\hline & \multirow[t]{2}{*}{9} & Kisaran & 30 & 34 & 30 & 30 & $32-34$ & $30-34$ \\
\hline & & Rata-rata & 30 & 34 & 30 & 30 & 33.5 & 31 \\
\hline
\end{tabular}




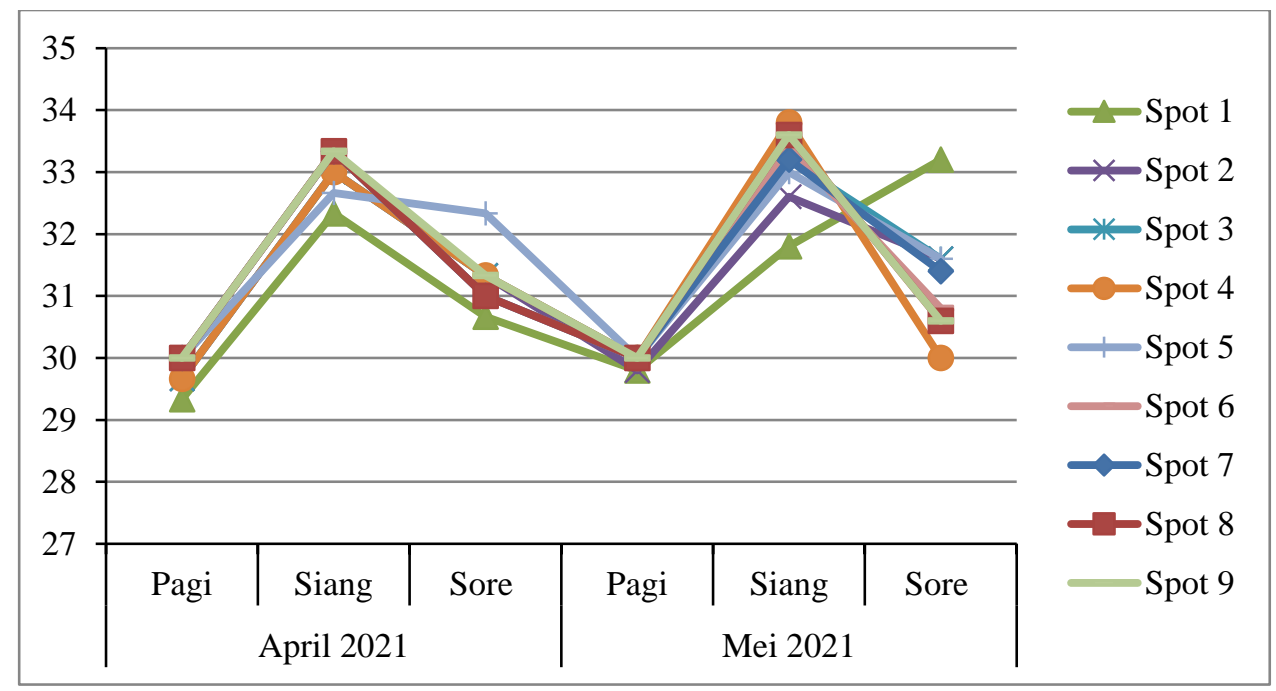

Gambar 3. Grafik Salinitas Perairan Pada 9 Spot Pengamatan Berbeda.

Nilai salinitas yang diperoleh selama penelitian pada pagi dan sore hari pada tanggal 19 April 2021 rata-rata berkisar pada level 29 ppt yang berada pada Spot I terletak di Baruta Analalaki dan pada siang hari rata-rata berkisar pada level 32,50 ppt pada setiap Spot. Pada tanggal 12 Mei 2021 pada pagi hari rata-rata pada level 29,5-30 pada setiapa Spot ppt, pada siang hari 31,75-33,50 ppt pada tanggal 19 Mei pada setiap Spot, dan pada sore hari rata-rata salinitas berkisar pada level 31-33 ppt. Sedangkan pada tanggal 24 Mei 2021 pada pagi hari rata-rata pada level 30 ppt, pada setiap Spot pada siang hari 32-34 ppt dan pada sore hari 30-34 ppt pada tanggal 24 dan 31 Mei setiap Spot.

Salinitas adalah konsentrasi seluruh larutan garam yang diperoleh dalam air laut, dimana salinitas air berpengaruh terhadap tekanan osmotik air, semakin tinggi salinitas maka akan semakin besar pula tekanan osmotiknya (Gufran dan Baso, 2007 dalam Widiadmoko, 2013).

Nilai Salinitas yang diperoleh pada peneliitian pagi hari bulan April 2020 rata-rata berkisar pada level 29 ppt yang berada pada spot I terletak di Baruta Analalaki dan pada siang hari rata-rata berkisar 32,50 ppt pada setiap spot. Pada tanggal 3 Mei 2021 pada pagi hari rata-rata pada level 29,5-30 ppt pada setiap spot, pada sianng hari 31,75-33,50 ppt pada tanggal 10 Mei pada setiap spot, dan pada sore hari rata-rata Salinitas berkisar pada level 31-33 ppt. sedangkan pada tanggal 24 Mei 2021 pada pagi hari rata-rata pada level 30 ppt, pada spot siang hari 32-34 ppt dan pada sore hari 30-34 ppt pada tanggal 24 dan 31Mei pada setiap spot.

Nilai salinitas tersebut tidak berbeda jauh dengan nilai salinitas perairan Indonesia, dimana secara umum permukaan perairan Indonesia rata- rata berkisar antara 32-34\%o (Dahuri et al., 1996). Berdasarkan baku mutu air laut dalam Keputusan Menteri Negara Lingkungan Hidup No. 51 tahun 2004, sebagian besar nilai salinitas pada Spot pengamatan masih sesuai dengan baku mutu air laut untuk biota laut. Hutabarat dan Evans (1984) menyatakan bahwa daerah estuaria adalah daerah dimana kadar salinitasnya berkurang karena adanya pengaruh air tawar yang masuk dan juga disebabkan oleh terjadinya pasang surut di daerah tersebut. Keragaman salinitas 
dalam air laut akan mempengaruhi jasad-jasad hidup akuatik berdasarkan kemampuan pengendalian berat jenis dan keragaman tekanan osmotik.

\section{Kecerahan}

Hasil pengukuran kecerahan pada lokasi penelitian tersaji pada tabel 4 dan gambar 4 dibawah ini.

Tabel 4. Hasil pengukuran kecerahan selama bulan April sampai dengan bulan Mei 2021

\begin{tabular}{|c|c|c|c|c|}
\hline \multirow{2}{*}{ Lokasi } & \multirow{2}{*}{ Spot } & \multirow{2}{*}{$\begin{array}{c}\text { Parameter } \\
\text { Kecerahan (m) }\end{array}$} & \multirow{2}{*}{$\begin{array}{c}\text { April } 2021 \\
\text { Siang }\end{array}$} & \multirow{2}{*}{$\begin{array}{c}\text { Mei } 2021 \\
\text { Siang }\end{array}$} \\
\hline & & & & \\
\hline \multirow{6}{*}{$\begin{array}{c}\text { I } \\
\text { Baruta Analalaki }\end{array}$} & \multirow{2}{*}{1} & Kisaran & $5,63-6,93$ & $5,61-6,82$ \\
\hline & & Rata-rata & 6.28 & 6.35 \\
\hline & \multirow{2}{*}{2} & Kisaran & $5,57-6,54$ & $5,58-6,74$ \\
\hline & & Rata-rata & 6.06 & 6.22 \\
\hline & \multirow{2}{*}{3} & Kisaran & $5,21-6,13$ & $5,21-6,21$ \\
\hline & & Rata-rata & 5.67 & 5.93 \\
\hline \multirow{6}{*}{$\begin{array}{c}\text { II } \\
\text { Baruta Doda }\end{array}$} & \multirow{2}{*}{4} & Kisaran & $5,58-6,97$ & $5,63-6,79$ \\
\hline & & Rata-rata & 6.28 & 6.44 \\
\hline & \multirow{2}{*}{5} & Kisaran & $5,76-7,06$ & $5,86-7,11$ \\
\hline & & Rata-rata & 6.41 & 6.72 \\
\hline & \multirow{2}{*}{6} & Kisaran & $6,54-7,28$ & $6,81-7,29$ \\
\hline & & Rata-rata & 6.91 & 7.16 \\
\hline \multirow{6}{*}{$\begin{array}{c}\text { III } \\
\text { Tolandona }\end{array}$} & \multirow{2}{*}{7} & Kisaran & $8,08-8,15$ & $8,09-8,15$ \\
\hline & & Rata-rata & 8.12 & 8.12 \\
\hline & \multirow{2}{*}{8} & Kisaran & $8,07-8,18$ & $8,10-8,14$ \\
\hline & & Rata-rata & 8.13 & 8.12 \\
\hline & \multirow{2}{*}{9} & Kisaran & $8,20-8,59$ & $8,12-8,16$ \\
\hline & & Rata-rata & 8.4 & 8.14 \\
\hline
\end{tabular}

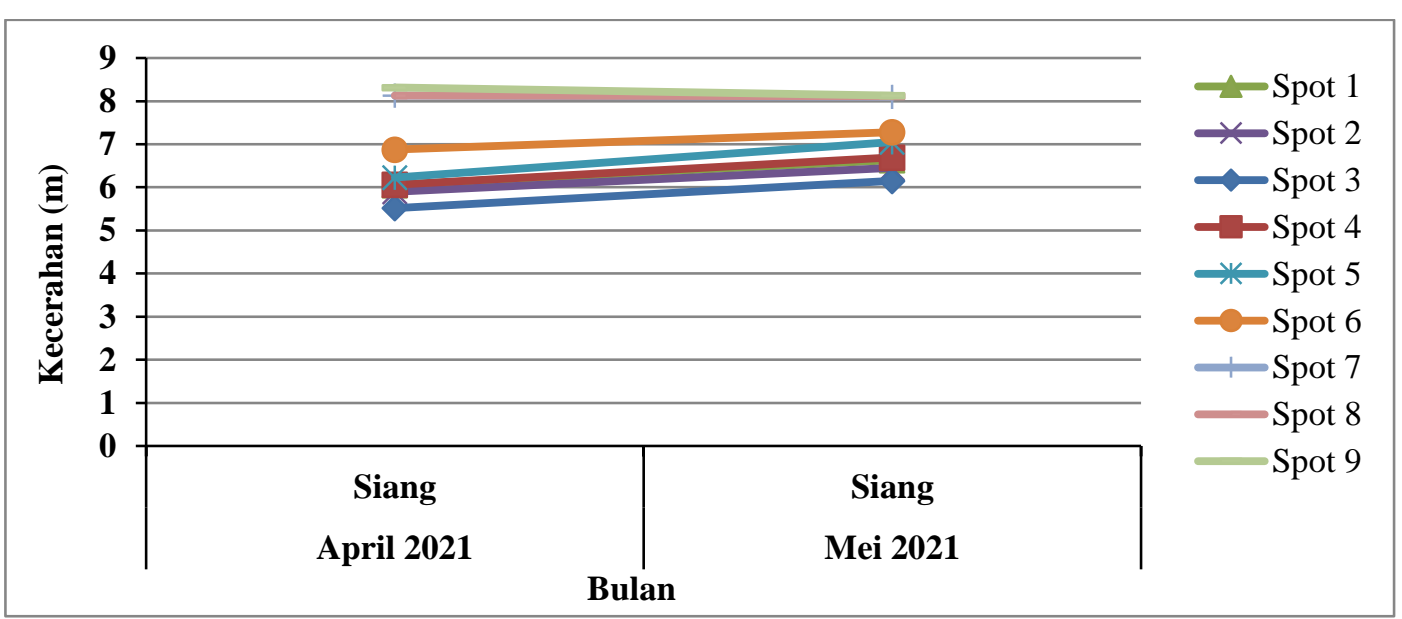

Gambar 4. Grafik Kecerahan Perairan Pada 9 Spot Pengamatan Berbeda Spot.

Kecerahan air tergantung pada warna dan kekeruhan. Kecerahan merupakan ukuran transparansi periaran, yang ditentukan secara visual menggunakan secchi disk. Nilai kecerahan dinyatakan dalam satuan meter. Nilai ini sangat dipengaruhi oleh 
keadaan cuaca, waktu pengukuran, kekeruhan, dan padatan tersuspensi serta ketelitian orang yang melakukan pengkuran (Effendi, 2003).

Berdasarkan hasil pengukuran dilapangan diketahui bahwa nilai kecerahan perairan Spot Penelitian Fakultas Perikanan pada Kecamatan Sangia Wambulu cukup bervariasi yaitu sekitar 5,21 hingga 8,16 m. Nilai kecerahan yang diperoleh pada penelitian masih layak untuk kegiatan budidaya rumput laut dan budidaya ikan. Kordi dan Tancung (2005), menyatakan bahwa kelayakan nilai kecerahan suatu perairan di atas $25 \mathrm{~cm}$. Bila kecerahan sudah mencapai kedalaman kurang dari $25 \mathrm{~cm}$, berarti akan terjadi penurunan oksigen terlarut secara dratis.

\section{Kecepatan Arus}

Hasil pengukuran kecepatan arus memperlihatkan kecepatan arus tertinggi pada Bulan Mei dengan kisaran 9,69-11, $38 \mathrm{~cm}$ /detik dengan nilai rata-rata 10,28 cm/detik. Sedangkan kecepatan arus terendah pada bulan April 2021 7,17-7,39 cm/detik dangan nilai rata-rata $7,28 \mathrm{~cm} /$ detik.

Tabel 5. Hasil pengukuran kecepatn arus selama bulan April - Mei 2021

\begin{tabular}{|c|c|c|c|c|c|c|}
\hline \multirow{2}{*}{ Lokasi } & \multirow{2}{*}{ Spot } & \multirow{2}{*}{$\begin{array}{l}\text { Parameter } \\
\text { Arus }\end{array}$} & \multicolumn{2}{|c|}{ April 2021} & \multicolumn{2}{|c|}{ Mei 2021} \\
\hline & & & Pagi & Siang & Pagi & Siang \\
\hline \multirow{6}{*}{$\begin{array}{c}\text { I } \\
\text { Baruta } \\
\text { Analalaki }\end{array}$} & \multirow{2}{*}{1} & Kisaran & $7,25-745$ & $8,11-8,51$ & $8,26-9,23$ & $8,53-9,84$ \\
\hline & & Rata-rata & 7.35 & 8.11 & 8.64 & 9.13 \\
\hline & \multirow{2}{*}{2} & Kisaran & $7,19-7,40$ & $7,74-8,30$ & $8,11-9,16$ & $8,38-9,72$ \\
\hline & & Rata-rata & 7.29 & 8.02 & 8.55 & 9.03 \\
\hline & \multirow{2}{*}{3} & Kisaran & $7,17-7,39$ & $7,72-8,29$ & $7,87-8,98$ & $8,11-9,53$ \\
\hline & & Rata-rata & 7.28 & 8 & 8.28 & 8.9 \\
\hline \multirow{6}{*}{$\begin{array}{c}\text { II } \\
\text { Baruta } \\
\text { Doda }\end{array}$} & \multirow{2}{*}{4} & Kisaran & $8,40-8,69$ & $8,35-8,36$ & $7,94-9,17$ & $8,59-10,41$ \\
\hline & & Rata-rata & 8.54 & 8.36 & 8.56 & 9.42 \\
\hline & \multirow{2}{*}{5} & Kisaran & $8,71-8,73$ & $8,36-8,53$ & $8,26-9,23$ & $9,35-10,91$ \\
\hline & & Rata-rata & 8.72 & 8.44 & 8.67 & 9.92 \\
\hline & \multirow{2}{*}{6} & Kisaran & $9,62-9,70$ & $8,39-8,56$ & $8,49-9,40$ & $9,39-11,01$ \\
\hline & & Rata-rata & 9.66 & 8.48 & 8.92 & 10.04 \\
\hline \multirow{6}{*}{$\begin{array}{c}\text { III } \\
\text { Tolandona }\end{array}$} & \multirow{2}{*}{7} & Kisaran & $9,73-9,77$ & $8,43-8,61$ & $8,83-9,75$ & $9,76-11,22$ \\
\hline & & Rata-rata & 9.75 & 8.52 & 9.29 & 10.26 \\
\hline & \multirow{2}{*}{8} & Kisaran & $9,71-9,76$ & $8,43-8,61$ & $8,89-9,77$ & $9,69-11,38$ \\
\hline & & Rata-rata & 9.74 & 8.52 & 9.3 & 10.28 \\
\hline & \multirow{2}{*}{9} & Kisaran & $9,72-8,43$ & $8,44-8,62$ & $8,86-9,76$ & $9,67-11,35$ \\
\hline & & Rata-rata & 9.75 & 8.53 & 9.29 & 10.28 \\
\hline
\end{tabular}




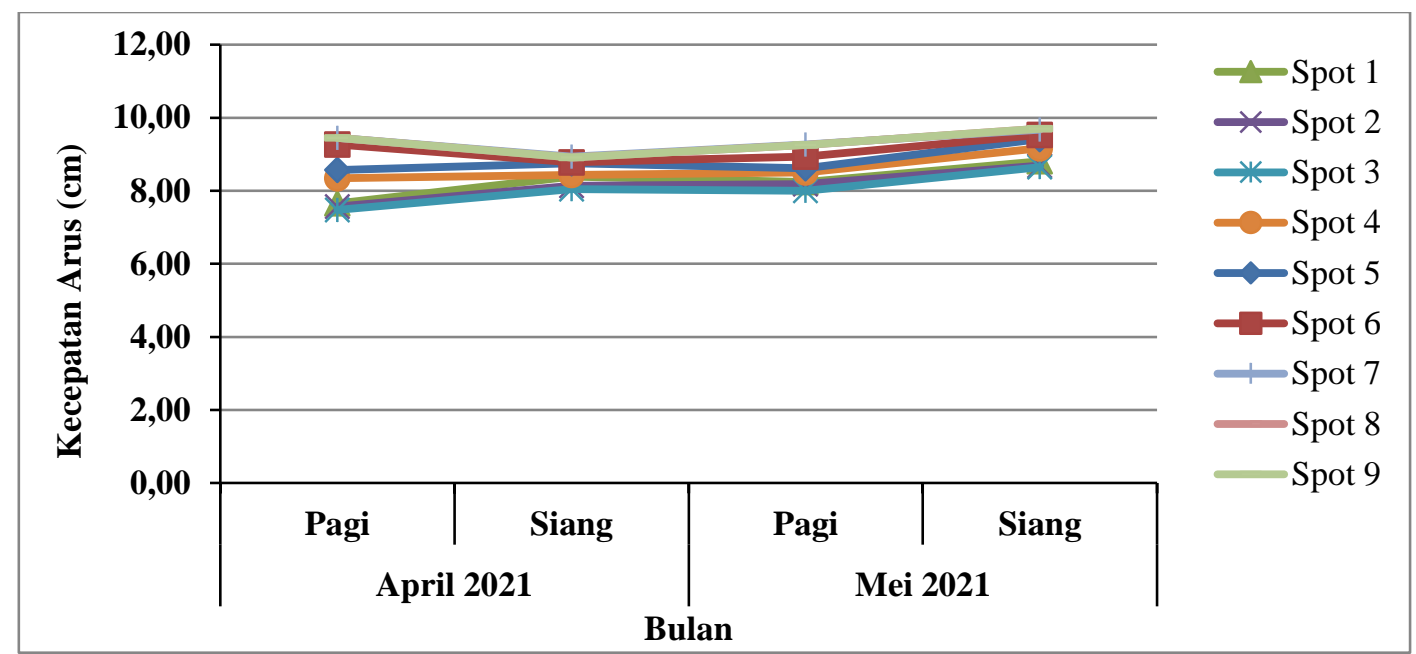

Gambar 5. Grafik Kecepatan Arus Perairan Pada 9 Spot Pengamatan Berbeda.

Kecepatan arus selama pengamatan berkisar antara 7,01 - 11,38 cm/detik. Kecepatan arus yang ideal untuk budidaya rumput laut berkisar dengan nilai optimum 20-40 cm/det (SNI, 2010), Arus yang diukur 1 meter dari permukaan laut. Arus dapat memberi pengaruh baik dan pengaruh buruk dalam kegiatan budidaya rumput laut. Pengaruh baiknya yaitu rumput laut memerlukan arus untuk membantu ketersediaan pasokan nutrien. Sinaga (1999) mengemukakan bahwa semakin kuat arus suatu perairan maka pertumbuhan alga laut akan semakin cepat karena difusi nutrien ke dalam sel thallus semakin banyak, sehingga metabolisme dipercepat. Pengaruh buruknya yaitu jika arus terlalu besar akan merusak rumput laut tersebut. Lokasi untuk budidaya K. alvarezii harus terlindung dari arus dan hempasan ombak yang besar. Apabila hal ini terjadi, arus dan ombak akan merusak dan menghanyutkan tanaman.

Menurut Wahyuningrum (2001), arus air yang baik akan membawa nutrisi bagi rumput laut untuk tumbuh serta untuk membersihkan kotoran maupun endapan yang menempel. Rumput laut akan tumbuh dengan baik karena ada kesempatan menyerap nutrisi (makanan) dari air dan proses fotosintesis tidak terganggu. Kecepatan arus yang terlalu kuat menyebabkan tanaman kesulitan menyerap nutrisi (makanan) yang berguna bagi pertumbuhan. secara umum arah arus di perairan Kecamatan Sangia Wambulu dan pulau panjang adalah Satu arah (unidirectional) yang bergerak dari Utara ke Selatan dan sebaliknya. Menurut Ariyati, $d k k$ (2007). Arah arus perlu diketahui untuk menentukan gambaran umum wadah budidaya sehingga sirkulasi air tetap lancar dan terkendali.

\section{Pasang Surut}

Hasil pengamatan kondisi pasang sarut selama penelitian tersaji pada tabel dibawah ini.

Tabel 6. Hasi pengamatan psang surut selama penelitian

\begin{tabular}{cclcccccc}
\hline \multirow{2}{*}{ Lokasi } & \multirow{2}{*}{ Spot } & \multirow{2}{*}{$\begin{array}{c}\text { Parameter } \\
\text { Pasang Surut }\end{array}$} & \multicolumn{3}{c}{ April 2021 } & \multicolumn{3}{c}{ Mei 2021 } \\
\cline { 3 - 8 } & & Pagi & Siang & Sore & Pagi & Siang & Sore \\
\hline \multirow{2}{*}{ Baruta } & \multirow{2}{*}{1} & \multirow{2}{*}{ Kisaran } & $8,92-$ & $8,74-$ & $8,95-$ & $8,85-$ & $8,87-$ & $8,84-$ \\
Analalaki & & 11,96 & 12,19 & 12,32 & 12,19 & 12,10 & 12,17 \\
& & \multirow{2}{*}{ Rata-rata } & $\mathbf{1 0 . 4 4}$ & $\mathbf{1 0 . 4 6}$ & $\mathbf{1 0 . 6 3}$ & $\mathbf{1 0 . 4 8}$ & $\mathbf{1 0 . 4 6}$ & $\mathbf{1 0 . 5}$ \\
\hline
\end{tabular}




\begin{tabular}{cclcccccc}
\hline \multirow{2}{*}{$\begin{array}{c}\text { Baruta } \\
\text { Doda }\end{array}$} & \multirow{2}{*}{2} & \multirow{2}{*}{ Kisaran } & $8,88-$ & $8,64-$ & $8,90-$ & $8,54-$ & $8,09-$ & $8,57-$ \\
& & & 11,86 & 12,15 & 11,32 & 11,89 & 12,06 & 12,17 \\
\cline { 3 - 8 } & & Rata-rata & $\mathbf{1 0 . 3 7}$ & $\mathbf{1 0 . 3 9}$ & $\mathbf{1 0 . 1 1}$ & $\mathbf{1 0 . 0 2}$ & $\mathbf{1 0 . 1 2}$ & $\mathbf{1 0 . 1 3}$ \\
\hline \multirow{3}{*}{ Tolandona } & \multirow{2}{*}{3} & \multirow{2}{*}{ Kisaran } & $8,95-$ & $8,57-$ & $8,91-$ & $8,53-$ & $8,09-$ & $8,56-$ \\
& & 11,76 & 12,12 & 11,52 & 12,12 & 12,02 & 12,12 \\
& & Rata-rata & $\mathbf{1 0 . 3 5}$ & $\mathbf{1 0 . 3 4}$ & $\mathbf{1 0 . 2 2}$ & $\mathbf{1 0 . 3 4}$ & $\mathbf{1 0 . 1}$ & $\mathbf{1 0 . 3 7}$ \\
\hline
\end{tabular}

Hasil menunjukan bahwa kondisi pasang tertinggi pada Spot 1 dan terendah pada Spot 2 dan 3.

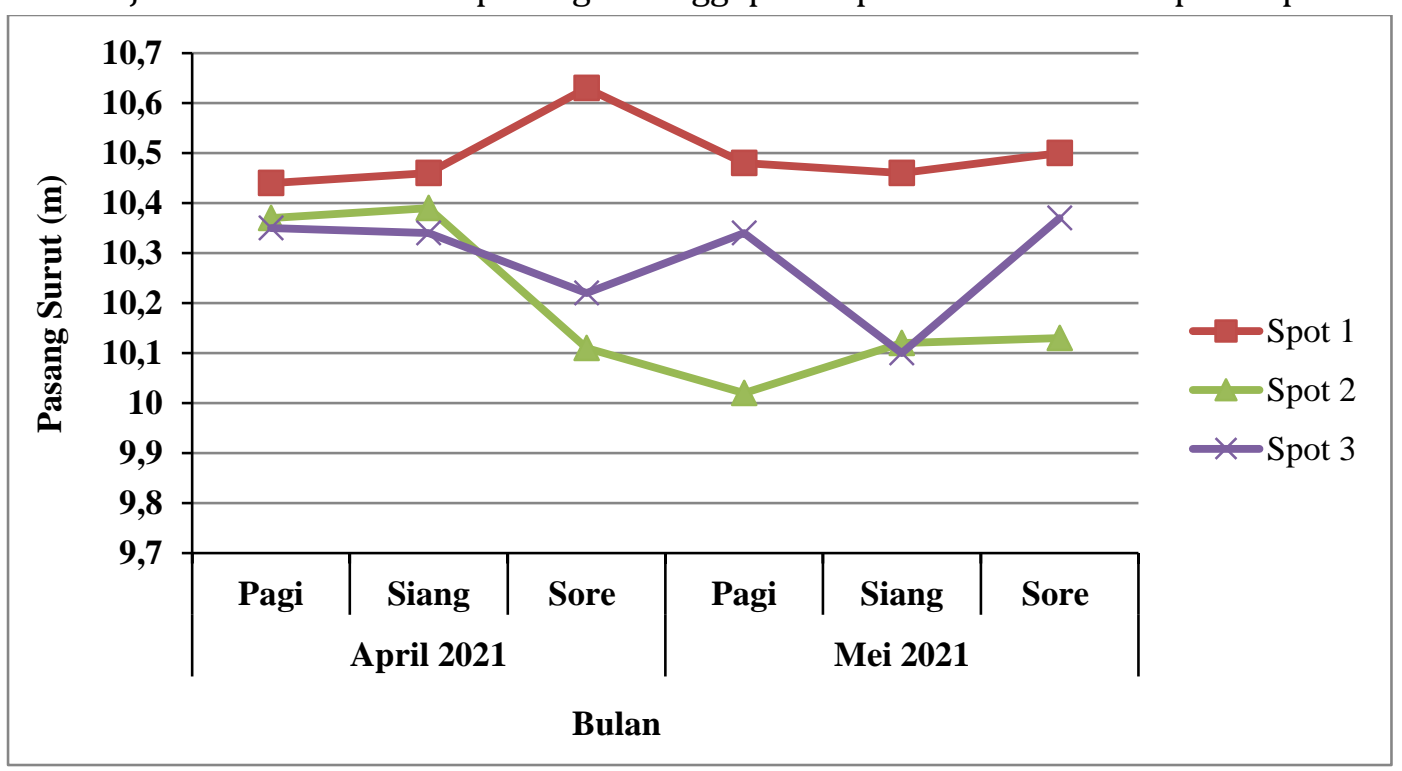

Gambar 6. Grafik Pasang Surut Perairan Pada 9 Spot Pengamatan Berbeda Spot.

Hasil pengamatan menunjukkan bahwa kondisi pasang surut relative tidak berbeda antar Spot pengamatan. Nilai pasang tertinggi adalah 8,74-12,19 meter, dengan rata-rata 10,63 meter terjadi pada bulan April sedangkan surut terendah berkisar 8,4711,27 meter dengan rata-rata 9,83 meter terjadi pada bulan Mei. Kondisi pasang surut ini masih layak untuk kegiatan budidaya rumput laut dan budidaya ikan. Pasang surut dipengaruhi oleh gaya tarik bumi, bulan dan matahari (Hutabarat, 2008).

Matahari mempunyai massa 27 juta kali lebih besar dari massa bulan, dan jaraknya pun sangat jauh dari bumi (rata-rata 149,6 juta km). sedangkan bulan, sebagai satelit kecil, jaraknya sangat dekat dengan bumi (rata-rata 381,160 km). dalam mekanika alam semesta, jarak lebih menentukan dari pada massa. Oleh karenanya bulan mempunyai peranan yang lebih besar dari pada matahari alam menentukan pasang surut (Notji 2002).

\section{Kesimpulan}

\section{KESIMPULAN DAN SARAN}

Berdasarkan hasil pengamatan dan pembahasan yang telah dilakukan maka pentingnya menarik beberapa kesimpulan yaitu :

1. Parameter fisik yaitu suhu perairan berkisar 26 hingga $28^{\circ} \mathrm{C}$, salinitas 29 - $31 \mathrm{ppt}$, kecerahan 5 hingga 7,3 m, dan kecepatan arus 7,01 - 11,38 cm/detik. Secara umum keberadaan kualitas air fisik; suhu dan kecerahan masih berada pada kondisi yang relatif baik. 
2. Pada dasarnya perairan Kecamatan Sangia Wambulu yakni sekitar Desa Baruta Analalaki, Baruta Doda dan Tolandona masih dapat di gunakan usaha budidaya.

\section{DAFTAR PUSTAKA}

[SNI 7579.2:2010] Standar Nasional Indonesia. 2010. Produksi Rumput Laut Kotoni (Eucheuma cottonii)-Bagian 2: Metode long-line. Jakarta (ID): Badan Standardisasi Nasional.

Ariyati RW, Sya'rani L, dan Arini E. 2007.Analisis Kesesuaian Perairan Pulau Karimunjawa dan Pulau Kemujan Sebagai Lahan Budidaya Rumput Laut Menggunakan Sistem Informasi Geografis. Jurnal Pasir Laut. 3(1): 27-45 hal.

Boyd, C. E. and F. Lichtkoppler. 1982. Water Quality Management in Pond Fish Culture. Auburn University, Auburn.

Effendi, Hefni. 2003. Telaah Kualitas Air Bagi Pengelolaan Sumber Daya dan Lingkungan Perairan. Kanisius( Anggota IKAPI ), Jakarta.

Hasan, M. I. 2002. Pokok-pokok Materi Metologi Penelitian dan Aplikasinya. Ghalia Indonesia, Jakarta, 260 hlm.

Hutabarat dan evans, 2008. Pengantar Oceanografi Jakarta : Penerbit Universitas Indonesia (UI- Press).

Hutabarat dan Evans. 2001. Pengantar Oseonografi. Universitas Indonesia. Jakarta.

Nirmala K, Ratnasari A dan Budiman S. 2014. Penentuan kesesuaian lokasi budidaya rumput laut di Perairan Teluk Gerupuk - Nusa Tenggara Barat menggunakan penginderaan jauh dan SIG. Jurnal Akuakultur Indonesia 13 (1), 73-82 hal.

Purwanto, E. A dan R. S. Dyah. 2007. Metode Penelitian Kuantitatif. Gava Media, Yogyakarta, $47 \mathrm{hlm}$.

Republik Indonesia. 2004. Keputusan Menteri Negara Lingkungan Hidup Nomor 51 Tahun 2004 Tentang Baku Mutu Air Laut. Jakarta: Sekertariat Negara.

Sinaga T. 1999. Sturuktur Komunitas Rumput Laut di Perairan Rataan Terumbu Pulau Pari, Kepulauan seribu, Jakarta Utara (Skripsi). Fakultas Perikanan dan Ilmu Kelautan, Institut Pertanian Bogor. Bogor.

Wahyuningrum PI. 2001. Studi evaluasi kesesuaian wilayah perairan teluk lampung untuk budidaya rumput laut Eucheuma dengan pemanfaatan penginderaan jauh dan system informasi geografi (SIG) [Skripsi]. Bogor: Institut Pertanian Bogor

Widiadmoko W. 2013. Pemantauan Kualitas Air Secara Fisika dan Kimia di Perairan Teluk Hurun Balai Besar Pengembangan Budidaya Laut (BBPBL) Lampung. Politeknik Negeri Lampung. Bandar Lampung. 